\title{
Reproduction Performance of Kashmir Merino Sheep at an Organized Farm of Kashmir
}

\author{
Ishfaq Ahamad, Mubashir Ali Rather, Imran Bashir, Tariq A. Malik \\ Department of Sheep Husbandry, Sheep Breeding Farm, \\ Kralpathri, Budgam, Srinagar-190 008, Jammu and Kashmir, India.
}

Received: August 2021

Accepted: December 2021

\begin{abstract}
Background: Kashmir Merino sheep breed is being developed by croosing native sheep breeds like poonchi, bakerwal and gadi with exotic sheep breeds like Australian Merino Rams. Currently Kashmir Merino sheep breed is being maintained at the 8 Government sheep breeding farms of Kashmir Valley.

Methods: The data pertaining to Kashmir Merino sheep ranging over 18 years (2001 to 2010 and 2012 to 2019 ) was analysed using descriptive stastics to estimate lambing and twining percentage, incidence of abortion, dystocia and still births. Data was obtained from lambing records of Kashmir Merino sheep, maintained at Sheep Breeding Farm Kralpathri. Result: In present investigation, overall percentage of lambing and twining was $82.49 \%$ and $0.33 \%$, respectively and incidence of rate of abortions, still births and dystocia of $1.29 \%, 1.20 \%$ and $0.91 \%$, respectively were observed in Kashmir Merino sheep. It was observed that with increase incidence of still births, dystocia and abortions, there is decrease in lambing percentage whereas incidence of twining percentage increases lambing percentage significantly. The lambing percentage can be increase by improving management and Fec-B intrograssion in Kashmir Merino sheep.
\end{abstract}

Key words: Abortion, Dystocia, Kashmir merino, Lambing, Reproduction, Still birth, Twinning.

\section{INTRODUCTION}

Reproduction in sheep is the most critical factor for production and success operation at the sheep farm. Reproductive performance is evaluated on the basis of lamb crop born for the given lambing season. Reproductive performance vary between farm, breed, production system, and geographic area. Crossbredding programme was approved to improve the production potential of native sheep breeds (Rather et al., 2021). Kashmir Merino sheep is crossbred sheep developed by crossing many exotic and native sheep breeds for good quality wool production. The genetic groups used for development of Kashmir Merino sheep include Poonchi, Bakerwal and Gadi. Lambing percentage is an important factor which determines overall reproductive performance of an animal along with age at first lambing and inter-lambing interval. The lambing percentage determines overall profitability of sheep enterprises. However, it is strongly influenced by environmental factors including different reproductive disorders whereas genetic intervention have very little role as the trait has very low heritability and associated genetic variance. Still births and abortions drastically decrease overall lambing percentage whereas twining percentage improves it. The present study was therefore designed to study lambing percentage and twining percentage, incidence of abortion and still births at an organized farm of Kashmir over the years.

\section{MATERIALS AND METHODS}

The data pertaining to Kashmir Merino sheep breed maintained at Sheep Breeding Farm Kralpathri were utilized to estimate lambing and twining percentage, incidence of abortion, dystocia and still births. The data were obtained from lambing records maintained at the farm. The farm is located at $33^{\circ} 53^{\prime}$ latitude $\mathrm{N}$ and $74^{\circ} 37^{\prime}$ longitude $\mathrm{E}$. The farms adopts semi intensive and semi migratory method of management. The sheep are stall-fed during winter and only 8 to 9 hours of grazing were provided during summer. The sheep are migrated to high land pastures for 80 to 90 days from mid June to mid September. The feed and fodder are provided @ $0.5 \mathrm{~kg}$ and $1.5 \mathrm{~kg}$ per animal per day, respectively during stall feeding. Ewes were mated during early autumn after screening for Brucellosis. The ewes were divided into groups based on body weight and wool yield traits, each group consisting of about 100 ewes. Paint was applied on the brisket region of selected rams and put into the pens with allotted group of ewes during night. Tupping was recorded in the morning and evening. The lambing percentage, twining percentage, incidence of abortion, dystocia and still births were computed using descriptive statistics (Snedecor and Cochran 1994). Lambing percentage was calculated by the following formula:

Lambing percentage $=$

$$
\frac{\text { Number of lambs born alive }}{\text { Number of ewes exposed to ram during tupping }} \times 100
$$

\footnotetext{
${ }^{*}$ Corresponding author's E-mail: secretdeal420@gmail.com
} 


\section{RESULTS AND DISCUSSION}

The overall percentage of lambing and twining was $82.49 \%$ and $0.33 \%$, respectively and incidence of abortions, still births and dystocia of $1.29 \%, 1.20 \%$ and $0.91 \%$, respectively were observed in Kashmir Merino sheep in present investigation (Table 1). The results with respect to twining percentage were in consonance with the results of Madras red sheep (Raman et al., 2003), Ganjam sheep (Mishra et al., 2004) and Coimbatore sheep (Kandasamy et al., $2006)$, who reported twining percentage of $1.06 \%, 0.5 \%$ and $1.10 \%$, respectively. However, it was reported that the overall percentage of lambing and twining was $93.56 \%$ and $1.87 \%$ in migratory sheep and $91.50 \%$ and $1.52 \%$ in non-migratory sheep in Tamil Nadu (Singaravadivelan et al., 2014). Rather M.A. et al., 2021 reported number of lambs born per ewe (NLBE), number of lambs weaned per ewe (NLWE), litter size (LS) and sex ratio (SR) as $3.56 \pm 0.11,3.20 \pm 0.10$, $48.32 \pm 0.04$ and $1.06 \pm 0.01$, respectively in Kashmir Merino sheep. In native Bengal $\times$ Garole sheep the litter size of 1.9 was reported (Banerjee 2008) and in Garole $\times$ Deccani sheep the same was reported as 1.6 (Nimbkar et al., 2002). In Native sheep $48 \%$ single and $52 \%$ twins and triplets, respectively were reported (Rahman and Huq, 1976). The average litter size of 1.7 with $40 \%$ single, $53 \%$ twins, $5 \%$ triplets and $1.7 \%$ quadruplets were stated in Garole sheep (Sharma et al., 1999). However, the average lambing frequency of 1.6-1.9 (Bose et al., 1999) and litter of 2 and at subsequent lambing 2.3 was reported in Garole sheep (Pan et al., 2004) (Singh, 1996).

In Changthangi sheep, the lambing percentage reported was between $60-70 \%$ and incidence of twinning less than 1\% (Ganai et al., 2011). The averages twinning percentage of $5.2 \%$ and $3.55 \%$ in Mengali Sheep was observed at two different research stations (Tariq et al., 2011). In Kashmir Merino sheep and Fec-B introgressed Kashmir Merino sheep, the reported litter size was $1.08 \pm 0.03$ and $1.40 \pm 0.04$, respectively (Rather et al., 2019). In another study of Kashmir Merino sheep, overall lambing percentage was $91.48 \%$ with $1-4 \%$ twining (Want et al., 2020). Absence of twining in Mecheri sheep breed of southern zone of Tamil Nadu was reported (Jagatheesan, 2001). However, the recorded litter size of 1.7 in Garole sheep, with percentage of single, twin, triplet and quadruplet birth of $42 \%, 43 \%, 15 \%$ and $0.2 \%$, respectively (Bose et al., 1999). Similarly, the reported litter size of 1.9 was observed in native Bengal Garole sheep (Banerjee 2008).
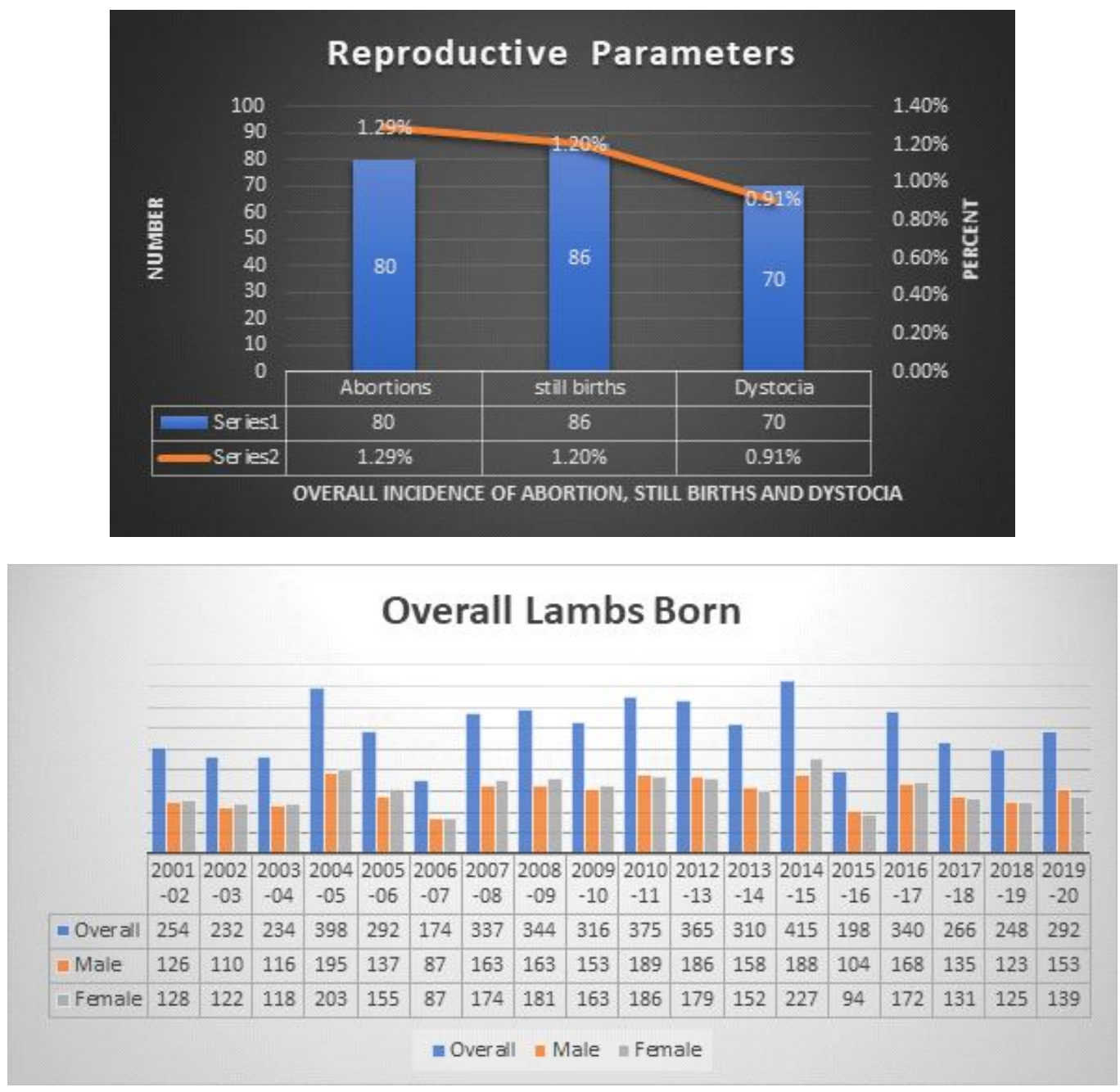


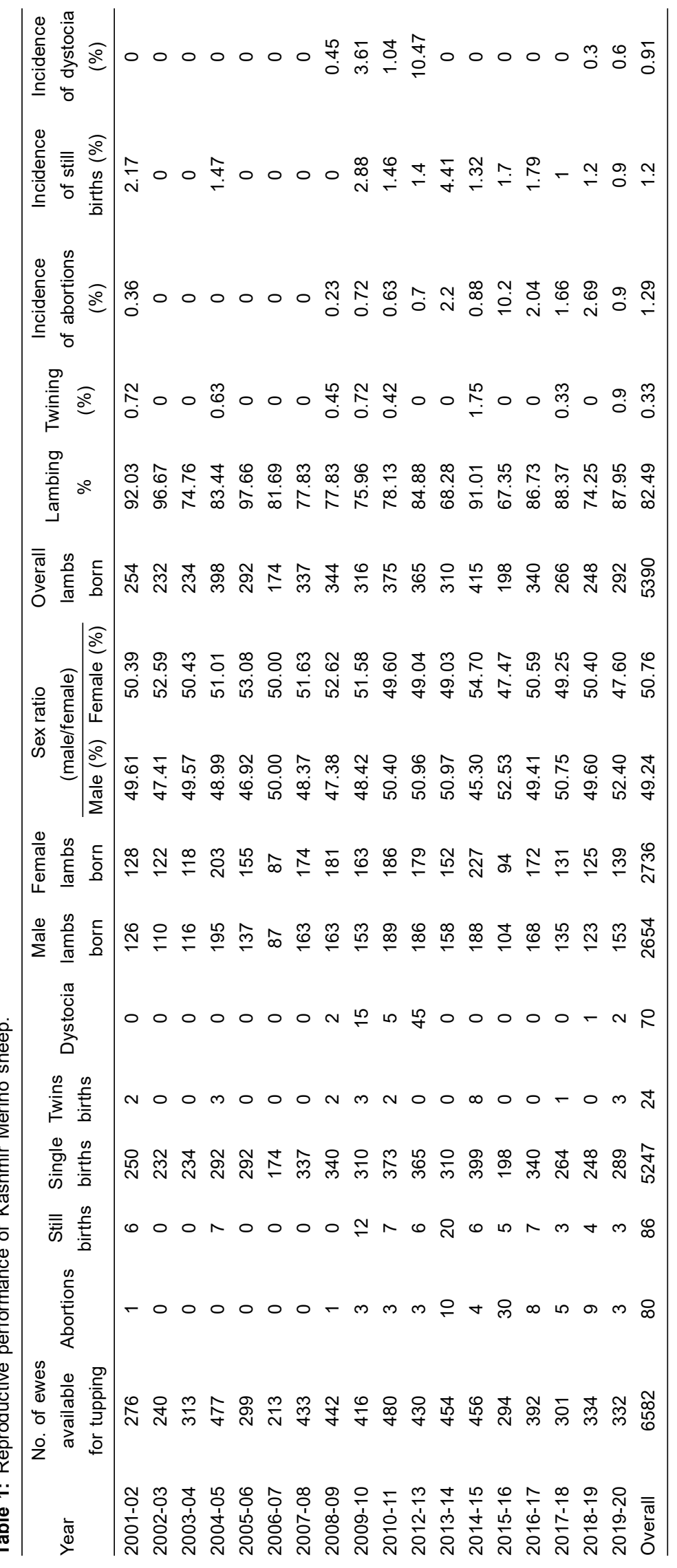


The lambing percentage presented the inconsistent trend over the years. This can be attributed to difference in management and nutrition provided to the ewes during pregnancy and estrous cycle in different years. The highest and lowest lambing \% was observed in 2005-06 and 2015-16, respectively. The lowest lambing percentage in $2015-16$ can be attributed to highest incidence of abortions $(10.2 \%)$ and still birth $(1.7 \%)$. Similarly, highest lambing percentage in 2005-06 followed by 2002-03 may be attributed to the fact that no incidence of still births, dytocia and abortions was observed in these years. The number of live lambs born per lambing season is an important trait to boost sheep production and to increase total weight weaned per dam than the growth rate/lamb. The lambing percentage in Kashmir Merino sheep can be improved by genetic innervation like Fec-B intrograssion and improving management and hygiene at farms. The genetic selection for improving lambing percentage will have little impact as it is a fitness trait having low heritability and genetic variation. Further, non-availability of real time and reliable data to understand genetic variability pertaining to lambing percentage in Kashmir Merino sheep makes it an uphill task. The overall sex ratio (SR) of 49.24 and 50.76 male and female, respectively was observed in the present study. As the sex is determined at the union of gamete and it is irrelevant that any factor actually affects the sex of the lamb. Kumar et al. (2021) reported SR of $50.43 \pm 0.28$ in Malpura and $51.05 \pm 0.32$ in Avikalin sheep. Kumar et al. (2021) also reported non-significant effect of birth type, parity and period of birth on SR. The variation among periods may be caused sampling variances in lambs born to a particular sex. Lowest SR was observed in first period 1997-2000 and highest SR was observed in third period (2004-2006) 55.49 \pm 0.06 .

\section{CONCLUSION}

Overall lambing percentage of $82.49 \%$ in Kashmir Merino sheep was observed in the present study. The trait is significantly influenced by management and nutrition. High incidence of still birth and abortions decrease lambing percentage significantly. Hence improving management at farm will increase lambing percentage and overall production.

\section{REFERENCES}

Banerjee, R. (2008). Conservation and in situ development of a prolific indigenous sheep in the Sundarban and Sagar Island, Ph.D Thesis, University of Calcutta, Koltata, West Bengal, India.

Bose, S., Duttsgupta, R. and Maitra, D.N. (1999). Phenotypic characteristics and management practices of Bengal sheep. The Indian Journal of Small Ruminant. 15: 18-22.

Ganai, T.A.S., Misra, S.S., Sheikh, F.D. (2011). Description of Changthangi sheep of Ladakh. The Indian Journal of Small Ruminants. 17(1): 32-40.

Jagatheesan, P.N.R. (2001). Performance of Mecheri breed of sheep in its home tract, Ph.D Thesis submitted to Tamil Nadu Veterinary and Animal Sciences University Chennai, 51.
Kandasamy, N., Paneerselvam, S., Devendran, P. and Thiruvenkadan, A.K. (2006). Final report on survey evaluation and characterization of Coimbatore sheep breed. Department of Animal Genetics and Breeding, VC and RI, Namakkal.

Kumar, A., Misra, S.S., Sharma, R.C. and Gowane, G.R. (2021). Genetic parameters for sex ratio in an organised sheep farm. Indian Journal of Small Ruminants. 27(1): 31-36.

Mishra, P.K., Barik, N., Patro, B.N. and Nayak, S. (2004). Production potentiality of Ganjam sheep under extensive management. The Indian Journal of Small Ruminants. 10(2): 171-172.

Nimbkar, C., Ghalsasi, P.M., Walkden-Brown, S.W., Kahn, L.P. (2002). Breeding Program for the Genetic Improvement of Deccani Sheep of Maharashtra, India. $7^{\text {th }}$ World Congress of Genetics Applied to Livestock Production, Montpellier, France. August 19-23.

Pan, S., Sahoo, A.K., Tantia, M.S. and Ahlawat, S.P.S. (2004). Garole Sheep, NATP (MM) on Animal Genetic resource bio-diversity. West Bengal University of Agriculture and Fisheries Science (WBUAFS), Mohanpur and Kolkata, West Bengal and NBAGR, Karnal, Haryana, India.

Rahman, M.M. and Huq, M.A. (1976). A comparative study of gestation period, prolificacy and lambing interval of native and upgraded Lohi sheep. Bangladesh Veterinary Journal. 10: 31-35.

Raman, K.S., Sundararaman, M.N., Haribhaskar, S. and Ganesakale, D. (2003). Bometrics and breed characteristics of Madras red sheep. The Indian Journal of Small Ruminants. 9(1): 6-9.

Rather, M.A., Hamadani, A., Malik, T.A., Bashir, I. and Ahmad, I. (2021). Genetic analysis of fitness traits of Kashmir Merino sheep at organized farms of Kashmir. Agricultural Science Digest. DOI: 10.18805/ag.D-5401.

Rather, M.A., Magray, S., Ahanger, S.A., Baba, M.A., Shah, M.M., Rather, T.A., Farooq, Y. and Abbas, Q. (2019). Effect of some non-genetic factors and Fec-B gene introgression on performance traits of Kashmir Merino Sheep. International Journal of Current Microbiology and Applied Science. 8(8): 444-449.

Sharma, R.C., Arora, A.L., Narula, H.K. and Singh, R.N. (1999). Characteristics of Garole sheep in India. Agri. 26: 57-64.

Singaravadivelan, A., Kumaravelu, N., Sivakumar, T., Karthickeyan, S.M.K. Vinothkumar, D. and Divyalakshmi, D. (2014). Reproductive performance of sheep in migratory and nonmigratory flocks in southern Tamil Nadu. Indian Journal of Veterinary and Animal Science Research. 43(5): 376-381.

Singh, R.N. and Bohra, S.D.J. (1996). Garole Sheep: A profile (Bengal breed of sheep locally known as Garole). The Indian Journal of Small Ruminants. 2: 38-43.

Snedecor, G.W. and Cochran, W.G. (1994). Statistical Methods, Eighth Ed. Lowa State University Press, Ames, USA.

Tariq, M.M., Bajwa, M.A., Abbas, F., Eyduran E., Awan, M.A., Ma- jed, R., Waheed A., Husssain, A., Bukhari F.A., Attiq, M.A., Ahmad, Z. and Javed, Y. (2011). Some morphological, fertility and growth traits for Mengali sheep of Balochistan, Pakistan. Journal of Institute of Science and Technology. 1(1): 63-68.

Want, Q.H., Banday, M.T., Adil, S., Khan, H.M. and Hussain (2020). A survey on evaluation of reproductive performance of Kashmir Merino sheep under field conditions. The Pharma Innovation Journal. 9(9): 113-117. 